\title{
Subaltern Geoaesthetics in Amitav Ghosh's The Hungry Tide
}

Nandana Dutta

\section{(2) OpenEdition \\ 1 Journals}

Electronic version

URL: https://journals.openedition.org/ces/4738

DOI: $10.4000 /$ ces.4738

ISSN: 2534-6695

Publisher

SEPC (Société d'études des pays du Commonwealth)

\section{Printed version}

Date of publication: 1 September 2016

Number of pages: $35-45$

ISSN: 2270-0633

\section{Electronic reference}

Nandana Dutta, "Subaltern Geoaesthetics in Amitav Ghosh's The Hungry Tide", Commonwealth Essays and Studies [Online], 39.1 | 2016, Online since 05 April 2021, connection on 18 June 2021. URL: http:// journals.openedition.org/ces/4738; DOI: https://doi.org/10.4000/ces.4738

\section{(c) $($ †) $\ominus$}

Commonwealth Essays and Studies is licensed under a Licence Creative Commons Attribution - Pas d'Utilisation Commerciale - Pas de Modification 4.0 International. 


\section{Subaltern Geoaesthetics in Amitav Ghosh's The Hungry Tide}

This article, on Amitav Ghosh's novel The Hungry Tide, examines the development of a postcolonial aesthetic that draws on India's experience with internal and external borders, on the specific border country of the Sundarbans and its ambivalent land-water space, and on a subaltern approach that has developed from being a historiographic method to an aesthetic choice in Amitav Ghosh's work. It argues that this subaltern geoaesthetic structures this novel and is characterized by an understanding of human and nature relationships that might be described by what Luce Irigaray has described as "approaching the other as other."

In the very middle of that mohona, we had crossed the line Bon Bibi had drawn to divide the tide country. In other words we had crossed the border that separates the realm of human beings from the domain of Dokkhin Rai and his demons. I realized, with a sense of shock, that this chimerical line was, to her and to Horen, as real as a barbed-wire fence might be to me (The Hungry Tide 223-34)

In the tide country, transformation is the way of life. (The Hungry Tide, 224)

And so it dawned on me: the tide country's faith is something like one of its great mohonas, a meeting not just of many rivers, but a circular roundabout people can use to pass in many directions - from country to country and even between faiths and religions (The Hungry Tide, 247)

Colonial experience in India and its neighbouring countries has been primarily an experience of the reconfiguration of familiar space, the drawing and redrawing of borders and the division of territory into smaller or more manageable administrative units. The legacy of these processes is seen in the postcolonial world which has either continued colonial demarcations or has instituted wholly new ones in the interests of more efficient governance. These have entered literary concerns in different ways. In the fraught modern history of what used to be called the Indian subcontinent novels written in English have frequently turned to political issues of space, either as backdrop or as central concern, and spoken of cartographies (Kamila Shamsie, Kartography) and maps (Nadeem Aslam, Maps for Lost Lovers), developed a numinous relationship to land (Romesh Gunesekera, Heaven's Edge) or tried to understand a territorially defining war (Tahmina Anam, The Golden Age). The political geography of South Asia has indeed provided rich material for novelists as they have developed subtle political critiques through representation of its continuous demarcations and the political struggles that have preceded them. Amitav Ghosh in his use of this setting in The Hungry Tide takes that extra step in making the nature of the terrain itself the aesthetic effect of the novel. The Hungry Tide is a novel about settlers in the precarious tide country of the Sundarbans who have to contend with the government's wildlife project, with the tides that erase and create land with alarming frequency, with the tigers and spirits who seem to have equally palpable presences, and with outsiders like Nirmal, Nilima, Kanai and Piya who come with alien ideas about improvement or about saving the environment and its endangered species. This essay examines the novel against the backdrop of border and space concerns in India's post-independence history, and in the light of Ghosh's 
associations with the subaltern studies project. Presenting as it does several kinds of borders - between human and animal, land and water, human and human, outsider and inhabitant, and educated and illiterate - the novel also shows contest and conflict which are however subverted by the way the tides erase divisions and compel coexistence. This region, with its poor and dispossessed inhabitants who live precariously on land that is always in danger of being claimed by the tides or the many rivers, and where human and animal contend for the same spaces, is ready material for subaltern engagement, while its unique features - rivers, tides, mangrove forests, tigers and dolphins - contribute to an aesthetic of mystery, transformation and beguilement. It is introduced by Ghosh through the description of the tide country in an amalgamation of real and mythical geography at the start of the novel and is then shown as a setting that marks its inhabitants and deeply influences the outsider. Ghosh has indeed consistently worked with a subaltern aesthetic of the border - the border creates subalterns since it is often the site of a face-off between the individual who legally or illegally crosses it and the authority that makes and mans it - that has taken different forms in several novels. The shadowy, difficult to discern border in The Shadow Lines, the traffic between past and present, this world-other world in The Calcutta Chromosome, the interchangeability of subject and object in In an Antique Land, and the movements between countries in The Glass Palace and the trilogy all attest to the way an awareness of place, borders and subalternity suffuses his work. But it is The Hungry Tide that is most evocative of such a border consciousness because the terrain participates in and determines narrative form and action.

I call this a "subaltern geoaesthetic" because it is founded on some of the elements of the subaltern studies historiographic project but, influenced by the terrain, is also a critique of this project. ${ }^{1}$ In this novel, Ghosh repeats elements of this historiographic mode in using a subaltern uprising and subaltern characters, but instead of only demonstrating failure, he also presents the world these people inhabit as transforming and ennobling, even as the easy acceptance of the mysterious and the mystical evokes respect for the other and creates an intuitive understanding of the limits and sanctity of spaces.

I attempt to understand the particular effect of the novel through subaltern "aesthetic" as opposed to "method," through issues of the border and through relationships fostered and taught by this unique border terrain that seem to be best explained by French feminist philosopher Luce Irigaray's concept of "two subjects" or "approaching the other as other." Irigaray's work on contiguous subjects is useful in understanding what Ghosh seems to be pointing to in this novel about the futility of contests and need to understand such coexistence through a respect for others' spaces. Her idea of "two subjects" helps to make sense of Ghosh's presentation of characters as inhabiting spaces that have to be respected and not violated. Nirmal and Nilima for instance work in the same space and yet are absorbed in very different kinds of work and this is true of Fokir, Moyna, Piya and Kanai, as of dolphin and tiger. Such separateness is also achieved through chapters that carry the names of characters or locations (for

1. The subaltern studies project, a deconstructive historiographic project that is positioned against the elitism of Indian nationalist historiography, began as studies of peasant uprisings of the colonial era and their failure to organize themselves into a national liberation movement (Guha "Aspects"). It extended and transformed the Gramscian idea of the subaltern to include all those who are subordinated, irrespective of "class, caste, age, gender and office or in any other way" (Guha "Preface" vii), in the process making visible a "politics of the people" (Guha "Aspects" 4). 
example, "Lusibari," "Fokir," "Kusum," "Nirmal and Nilima”) and are like little worlds. Aesthetic work in the novel involves this interpenetration and separation at all levels of structure.

\section{Subaltern Method or Subaltern Aesthetic}

The idea of an aesthetic of subalternism is not articulated by subaltern studies historians. Veena Das refers to a "subaltern perspective," involving a disruption of order, resistant figures who are also silent, since their speech "has been appropriated by [...] superior forms of authority" like the bureaucratic and the legal (Das 315), and an object of study which is "the 'contract' that such groups have been compelled to establish with forms of domination belonging to the structures of modernity" (313). Das sums up the dyad that informs this perspective - "to construct the moment of defiance is also to construct the form of legal-rational domination" (314) - a paradox that Ghosh seems able to transcend in the novel and that he presents as a masternarrative of order or governance against which figures like the Morichjhapi insurgents are placed. In another reflection on subaltern thinking Gautam Bhadra writes about the "subaltern mentality" which is constituted by both "defiance" and "[s]ubmissiveness to authority" (Bhadra 54). And Ranajit Guha has demonstrated that in many cases people's revolts "had all been inaugurated by planned and in some cases protracted consultations among the representatives of the local peasant masses" (Guha, "Counter-Insurgency" 195). These represent some of the positions within subaltern historiography. Subaltern history projects dealing in resistant figures, marginal and often repressed texts, and events silenced by official history are used by Ghosh whose grounding in this historiography allows him access to this method. But he then goes beyond the culture of subaltern history into a creative rethinking which involves grafting this subaltern perspective to the specificities of the India-East Pakistan and later India-Bangladesh border, evoking its terrain and its "life" and its continuing disputed status as essential aspects of this border condition.

Several essays have attempted to tease out the aesthetics of the The Hungry Tide. Divya Anand points to the ways in which water functions "as the agent of change [...] to steer clear of taking a moral or ideological stand while addressing the complex struggle between humans and animals for survival"; to "highlight the plight of both the dispossessed people and the threatened wildlife"; and to "keep the focus on the conflict, rather than on the resolution, making the novel itself and indeed its primary trope, water, the agents of political and social change" (Anand 23). Speaking of constructions of beauty in postcolonial texts, John J. Su argues that "[F]or Ghosh, questions of aesthetics are intimately related to questions of utopia, and he has consistently portrayed in positive terms his notion of a more egalitarian society," (68) developed most fully in The Glass Palace. Su also claims that "for Ghosh [...] aesthetic form emphasizes the permeability between lived and imagined worlds, and the experience of beauty emerges from a sense that alternatives are always apparent in everyday life" (72). Barras speaks of the mangrove ecosystem as a matrix of transculturation and as a chronotope, with the ecosystem, the cultural system and the narrative system interlinked to form an aesthetics of the tide (Barras). Vanessa Guignery writes of borders as an essential element in Indian English fiction: "The two antithetical dimensions of the line - rigid and shifting, constraining and challenging, necessary and dispensable - thus seem inseparable as a means of defining contemporary Indian productions" (Guignery 307). She uses De- 
leuze and Guattari's notion of the line of flight to theorize this condition, linking it to the historical reality of the line in India and to notions of lines as fences, stockades, and separations that she draws from both border theory and from Homi Bhabha's "border and frontier conditions" (Bhabha 17). Ghosh's work has also been examined as a "subaltern cosmopolitanism" or the mobility of ordinary people (Roy). These critiques veer tantalisingly towards a subaltern aesthetic, without actually naming it. Huggan and Tiffin see in the "shifting between a state of land and a state of water" an "objective correlative" for the "unstable past" of the Morichjhapi refugees (Huggan and Tiffin 187), but they stop short of identifying the novel's "superb evocation of the region of the sights, smells and sounds" as an aesthetic and merely say that "the lives of the people who live there are attuned to its ever shifting rhythms and moods" (187, emphasis added). My contention however is that the way the region, its inhabitants and their perception of animals, goddess and the waters are presented is not simply a matter of one reflecting or being an image of the other but is a formal and structural aspect of the novel.

Ghosh understands the geography, the politics and the sociology of the border as profoundly as its psychology - taking into account the conditions created by the borders and boundaries at the level of terrain and state and people. The features of this particular land-water border lends a fluidity to the processes of thought and this is at the core of Ghosh's aesthetics, realized exquisitely in the element of water from The Hungry Tide onwards. In fact this novel is a turning point in his work and marks an insight into the border condition that is deeper than that in The Shadow Lines which was also about the border but depended on a more predictable set of theoretical concerns about identity, divided houses and families, set against the historical events of Partition as experienced in eastern India.

\section{Borders, Boundaries and Contested Space}

Border consciousness and border aesthetics have predominantly emerged from the Mexican/Chicano/a experience of the border and carry traces of this site of origin. The liminal experience, the notion of hybridity and fluidity, the seamless movement between past and present and the emergence of a performance culture where the artist stages the border experience through a constantly changing art are standard aspects of border literature and culture. It is seen in the work of the Mexican writer, Juan Rulfo, whose novel PedroParamo is "made of silences, of hanging threads, of cut scenes, where everything happens in a simultaneous time which is no-time," (Rulfo qtd in Garcia $\mathrm{xx}$ ) or in the "artivist aesthetics" of the performance artist Richard Lou, made up of "creative expression, social activism and self empowerment" (Latorre np). Ghosh too has articulated the movement between past and present in all his novels, and has made remarkable use of subaltern/resistant figures whose silences are as powerful comments on the liminal border condition as is their speech. In The Hungry Tide however, Ghosh, by presenting the mysterious domain of Fokir, Bon Bibi, the dolphins and the waters, seems to be evolving an aesthetic that is made up of mystery, transformation and the beguiling multiple passages of the mohona. I argue that Ghosh's special take on border consciousness in this novel involves an understanding of the border as site of transgression but also as ensuring the necessary sanctity of different and individual spaces. His presentation of the Sundarbans creates an effect of spaces flowing into and 
blending in even as it demonstrates an intuitive respect for the other's space. It is in the context of this feeling for the other that I refer below to the work of Luce Irigaray on "two subjects."

Colonial and postcolonial demarcations in India have not only provided historical rationale but have also facilitated the evolution of an aesthetic of contested space (that is also a subaltern geoaesthetic since it draws on the marginal and the dispossessed in conflict with governments and in specific spaces) in the Indian English novel. The occasion for this material entering fiction is India's recent territorial history and some of the significant events that have resulted in the redrawing of land borders. The first of these of course is the well documented historical event of Partition which brought into existence the state of Pakistan (West and East) and produced a perennial dispute over borders. Concerns with lines and boundaries have continued to be a critical element of post-independence India's political life. Ever since the division of states on a linguistic basis was undertaken following independence, there have been problems with India's many linguistic and ethnic groups claiming further demarcations. A problem of majority language swamping minority languages was only one of the ways in which the relationship amongst different linguistic groups was figured. Territorial claims followed and several political movements that also came to be called autonomy movements brought in their wake more untidy divisions. Partition (that created Pakistan and India as two separate political entities), the linguistic division of India's territory into constituent states, newer states added to the original number following demands through people's movements, autonomous territorial councils, constitutional provisions (Article 370 of the Indian Constitution) for special treatment of some states, and of course smaller, less visible contestations among ethnic groups, settlers from different parts of India, and immigrants from neighbouring countries, have often caused confrontation and violence amongst people, even when these have not always left permanent territorial change. Contest over space seems to have become almost endemic in contemporary India. Such contests have thrown up issues of borders and boundaries, and of the subaltern against the state, often demonstrating some of the classic conditions that have been studied by the subaltern collective.

While there is a considerable body of critical and creative writing in the vernaculars on Partition and on internal divisions and resultant people's movements for autonomy these spatial events have not been visible in quite the same way in the Indian novel in English. The two writers who have directly represented India's territorial history - both internal and international - and have developed their aesthetics from this condition are Rushdie and Ghosh. Salman Rushdie uses Partition but also takes a tangential look at India's internal division or fragmentation into states in Midnight's Children and goes on to take note of what might be called border effects in subsequent novels like The Moor's Last Sigh and Shalimar the Clown. Other writers have occasionally mentioned borders or used them as backdrop - for example, Kiran Desai's The Inheritance of Loss is set against the movement for Gorkhaland in North Bengal and some English novels and short fiction from India's northeastern states speak of the complications, especially with regard to state boundary transgressions in the aftermath of newer states being carved out of existing larger states. Yet it is only in the works of these two writers that we see a profound and complex understanding of this modern predicament expressed through an aesthetics of fragmentation and fluidity (Rushdie), and an ethical approach to the other 
(Ghosh) that might be characterized as a distinct and specific aesthetics of the border. In Ghosh, this aesthetic is further inflected by his deep subaltern sympathies and the specific location that he has made his own. This combination of a location and a subaltern method appear together in The Hungry Tide in the distinctive tide water /mangrove forest terrain of the Sundarbans and a cast of "subaltern" characters and situations. A subaltern geoaesthetic is inaugurated for the first time by Ghosh in this novel and might be seen in three spatial contests or encounters that involve these elements - with the dolphins, with the tiger, and with the tide/storm combination at the end, and in all of which features the figure of Fokir and his instinctive "absorbed and deeply felt detachment" (this contradiction of terms is important in the presentation of Fokir). The terrain and its inhabitants determine this aesthetic which is also ethical since it places all entities on a single level field.

Contest distinguishes the border experience and is often accompanied by violence, massacres and state reprisals (the Morichihapi episode where the West Bengal government came down with force on the protesters and left many dead is crucial to the novel's subaltern method). And contest is critical to the version of border aesthetic that India's peculiar colonial and postcolonial experience of drawing boundaries has left in its wake. The component of contest is made up of several elements that also constitute the subaltern method, but this is only the first layer of aesthetic work in the novel. Contest is in fact also the occasion for the emergence of alternative relationships. Set against the now quite familiar subaltern historiographic method and using many of the stock elements of subaltern history writing, the novel represents a way of harmoniously apportioning space that recurs at important moments with the appearance of Fokir, the dolphins, and Nirmal, who didn't quite fit in either in Lusibari or with the Morichjhapi protesters, despite his desire to be with them in their struggle against the government. In fact Fokir or the young Tutul, or even the Nirmal of the diary - who are outside of readymade schemes - keep themselves free to associate in significantly different ways with their surroundings. The terrain educates/cultures these individuals into such behaviour, encouraging a symbiotic existence with the environment that is sustained parallely with the busy "improvements" in Lusibari and the carefully planned settlement at Morichjhapi. Ghosh uses borders and boundaries, conflicts between subaltern and government forces, and people and animals in the environment, to work up this two-tiered aesthetic that both draws on subaltern practice and institutes its critique. The more overtly subaltern method includes the following: a) the suppressed event (the Morichjhapi experiment of retrieving land in the slippery tidal country, clash with government and massacre); b) the lost and found text/scrap, (Nirmal's diary); and c) the subaltern resistants (Kusum and the other Morichjhapi settlers). Beneath or perhaps alongside it is the alternative realm of Fokir, the dolphins, the tiger and the mysterious rhythms of the Sundarbans and the magical domain of Bon Bibi.

Ghosh consciously makes the move into an aesthetic as opposed to a historiographic or anthropological method. As he declared in an interview after the publication of The Hungry Tide:

history or anthropology cannot give you the emotion, it cannot give you the affect, it cannot give you what individual characters feel as they experience history. So this is why I write novels, because I think novels can synthesize geology, history, personal relationships, emotion, everything. (Ghosh, "Interview" 103) 
The subaltern historical method which dealt with persons and events and little details still missed this kind of interweaving, synthesis and above all "emotion" or "affect." Gyan Prakash writes of the subaltern as divided within herself and when he says that "[t]he desire to recover the subaltern's autonomy is repeatedly frustrated because subalternity, by definition, signifies the impossibility of autonomy" (Prakash 9). He seems to be suggesting also the impossibility of synthesis in the sense that Ghosh speaks of. While the negative connotation of this description suggests failure, the character of Fokir for one would seem to belie the oversimplification of a concept like "autonomy" since in his own natural element of water he is autonomous, self sufficient and complete. The issue of subaltern agency or autonomy is given a different interpretation by Ghosh through the fullness of experience and the calm that Fokir represents.

Ghosh also reveals how conscious he was of the space he was working with in the novel: "when I began to deal with the Sundarbans, just discovering the layer upon layer upon layer, the dense layering of this history, [is what] makes this place possible, that gives it a location, [and] makes it continuously surprising" (Ghosh, "Interview" 105). The "intense layering" is what contributes to his two-tiered aesthetic.

\section{Subaltern Geoaesthetics}

As the novel unfolds and Ghosh presents the distinctiveness of the Sundarbans as a space that is water and land simultaneously, the tides keeping the region in a state of constant flux, the choice of region and event immediately establishes the futility of reading all border literatures in the same way. This is a border that is like no other - in what it separates and in its fluid existence:

There are no borders here to divide fresh water from salt, river from sea. The tides reach as far as three hundred kilometres inland and every day thousands of acres of forest disappear underwater only to re-emerge hours later. The currents are so powerful as to reshape the islands almost daily - some days the water tears away entire promontories and peninsulas; at other times it throws up new shelves and sandbanks where there were none before. (Ghosh, Hungry Tide 7)

This watery delta shared by two countries resists a universal notion of the border. As William van Schendel has shown, "the Boundary Commission's territorial surgery of Bengal resulted not in the simple bisection that is usually imagined but in the creation of no less than 201 territorial units" (Schendel 43). In his work on the Bengal Borderland, Schendel demonstrates in extensive detail how untidy the Radcliffe Line really turned out to be, not merely because of the vague nature of the commission but also because of the complex heterogeneity that it sought to divide into a simple binary of Muslim and non-Muslim, ignoring the fact that there were many other ethnic communities along the border abutting on Assam, Tripura and Burma (47).

The Hungry Tide, set in this fuzzy region, is about spaces, lines, conflict and contiguities. It represents humans and the natural existing alongside one another, sometimes trespassing into each other's territory but at other times respecting the other's space and dividing lines. The occasional encounter marks the transgression of one into another's space but is also shown as the occasion for cooperation and coexistence and for understanding the importance of these separate spaces. The two encounters with the tiger are examples of such transgressions - Kusum's father is killed by a tiger when he steps into the forest while the tiger that ventures into the village is killed by the 
villagers. Understanding each element for what it is marks Ghosh's depiction of the people and animals and rivers and tides in the novel. As the epigraphs reveal, the idea of a border is undercut by the tide country and its many rivers. A watery terrain that rubs out the border between India and Bangladesh, it suggests invisible, imagined lines, and the confluence of many rivers that is called "a mohona - a strangely seductive word, wrapped in many layers of beguilement," (7) displacing the notion of a border as a discernible and clear line with this unique formation that allows people to go in all directions. In this novel the mohona constitutes one of the important elements of Ghosh's border consciousness, a subaltern geoaesthetics that is learnt from the actual nature of the Sundarban tide country. Ghosh sources this particular form of border aesthetics from the ambivalent land-water character of the India-Bangladesh border and uses it to further his sympathies with and his understanding of the Other as separate and often impossible and unnecessary to fully understand. There are two aspects to the aesthetic that Ghosh develops in the novel. One is established in the very first chapter where the tide country and its natural and mythical origins are presented. A touch of mystery - a significant element of this aesthetic (and one that has become a distinctive feature of Ghosh's work) - is suggested through the simultaneously familiar and strange geography of the Sundarbans - familiar to Indian readers because the meeting of the two great rivers Ganga and Brahmaputra and many smaller ones forming the delta, the mangrove forest and its submergence in the tides, the tiger, and the river dolphin are all school reading for students in India; and strange because Ghosh estranges us from these elements by presenting them in mystical relationships - the geography of the region sustained and kept in balance by the fervent belief in the benign powers of Bon Bibi against the evil powers of Dokkhin Rai. A second aspect comes from the novel's immersion in the mystery and its unique effect of respecting spaces. Examples of this are seen throughout the novel. Nirmal and Nilima pursue different goals and Nirmal undertakes trips to Morichihapi towards the end of his life without disclosing anything to his wife. Fokir, whose wife Moyna would like to pull him back into the confines of domestic life, is wrapped up in a world of his own that is marked by his sensitive attitude to difference and this is shown through many small incidents - his non insistence when Piya refuses the food cooked by him on the boat (97) or his refusal to tell Piya the Bengali names for things (93); and through the way he appears complete and slightly aloof when he is in his natural element, in his boat on the waters. This is a swerve away from conventional subaltern practice which assumes the possibility of analysis to reveal and explain. The Morichjhapi incident indeed lends itself to subaltern study but the spill off from it is not quite so easy to discern.

\section{Approaching the Other as Other}

The Hungry Tide seems to give fictional representation to Luce Irigaray's sense of community. In an essay titled "Approaching the Other as Other," Irigaray evokes an alternative sense of community through sustaining of a sense of estrangement or mystery in the relationship of Self to Other. She writes of our usual tendency to grasp, know, seize and dominate and "transform[s] the life of the world into something finished, dead, because the world thus loses its own life, a life always foreign to us, exterior to us, other than us" (Irigaray 122). This becomes clearer when she says that "if we precisely grasped all that makes the springtime, we would without doubt lose the wondrous contem- 
plation in the face of the mystery of springtime growth" (122). This is the state that Kusum describes of Fokir when she says: "the river is in his veins" (245), and we see it illustrated in his blending of himself into the spirit of the water and his easy acceptance of the magical appearance of the dolphins which so enthuse and excite Piya. The point of this is made apparent when we see that Piya, despite partaking of this "wondrous contemplation" with Fokir, is trained to get behind the mystery. Fokir on the other hand is at ease with the mystery. As Piya draws his attention to the exhalations of the dolphins: "He nodded, but without showing any surprise; it was as though there were nothing unexpected about this encounter and he had known all along that they would be there" (113). If preserving a sense of the mysterious is part of an ethical acceptance of the other, this calm of Fokir's is part of his constant, unchanging consciousness of the mysterious in which he exists.

Anshuman Mondol points out that because the inhabitants of the Sundarbans are part of the environment, "their lives are dictated by the rhythms and force of the tides, by their relation to the soil and to the animals that surround them," (Mondol 176) while western environmentalism with its concern for the animal sometimes outweighing that for the human - as demonstrated by Piya when she is outraged by the villagers' treatment of the man-eating tiger they have captured - has "a propensity to separate humanity from "nature"' (Mondol 176). The precarious balance with which the line between the tigers and the humans is maintained in the novel is a representation of an aesthetic of contested space and something that is best understood in the kind of environment where these lines are difficult to maintain. Fokir's belief that "when a tiger comes into a human settlement, it's because it wants to die" (295) is an aspect of the way Ghosh imagines the necessity of borderlines whether they are between humans or between humans and animals; but these are lines that are fluid and flexible and understood by the people who are affected by them. Mondol suggests that "Ghosh represents this episode in a manner that closes the customary distance between humanity and animals" (Mondol 177). The contiguous existence that is represented by Ghosh in the novel is however not a matter of closing the gap so much as it is one of sustaining a distance, the lines that separate and keep each in its own element.

In her profound and luminous meditation on the Other, Irigaray says:.

\begin{abstract}
It is when we do not know the other, or when we accept that the other remains unknowable to us, that the other illuminates us in some way, but with a light that enlightens us without our being able to comprehend it, to analyze it, to make it ours. The totality of the other, like that of springtime, [...] touches us beyond all knowledge, all judgement, all reduction to ourselves, [...] the other as other, remains beyond all that we can predicate of him or her. The other is never this or that that we attribute to him or her. It is in so far as the other escapes all judgement on our part that he or she emerges as you, always other and nonappropriable by $I$. (123-4)
\end{abstract}

This is in Irigaray's terms "the you as irreducible to us, unknowable and imperceptible by us" (124). Efforts to understand Nirmal, the dolphin, Fokir, or the realm presided over by Bon Bibi are not realized by any of the seekers; what they discover is some aspect of themselves, not of the other; and this self understanding comes only with the willingness to leave the other in his/her/its own domain, not bring it through complete comprehension into one's own. Piya for instance does not find any answers to the questions she had brought with her to the Sundarbans, but discovers "the work of a lifetime" (126). In the course of her quest she discovers the many-sidedness of the mobona, 
and is transformed from the callow young woman she was at the start of the novel. In the chapter entitled "Listening," another significant component of this aesthetic - the separate and inviolate existence of each living creature - is revealed as Piya and Fokir sit "listening companionably to the Orcaella as they circled around the boat" (157) and Piya realizes "the immeasurable distance that separated her from Fokir" (159). She goes on to reflect wonderingly on the dolphin's life "where simply to exist was to communicate" and in the face of such mysterious affinities, she understands how "speech was only a bag of tricks that fooled you into believing that you could see through the eyes of another being" (159). This aspect of the novel's aesthetics is further seen in the chapter "A Killing" where Fokir's calm acceptance of the fate of the tiger that had crossed the line from its domain and entered human settlement leaves Piya shocked and outraged. She is unable to believe that the Fokir she thinks she "knows" should react so calmly (294-5), proving that she does not or cannot really know another human being. She takes refuge in Kanai's explanation that Fokir was just a fisherman and killed animals for a living (296-7).

The Hungry Tide takes its aesthetic cue from the unique border condition of the Sundarbans. While employing a number of subaltern elements that draw on borderlines and conflicts, the novel operates a shift by recognizing the border as a line that runs invisibly between the self and the other, between species, and between a discipline (in the case of Piya) and its objects of study. In trying to understand the significance of acceptance of the border, Irigaray's reflections are illuminating. They involve "opening of a world of one's own [...] in order to welcome the stranger, while remaining oneself and letting the stranger be other" (Irigaray 125). Through this hospitality-distance Irigaray reaches the idea of "two subjects" instead of subject and object (128). In the novel such a moment is reached when Piya and Fokir find themselves alone in the storm, Piya sitting astride a sturdy branch of a tall mangrove tree and facing the trunk, with Fokir seated behind her like a pillion rider on a motorcycle, and both tied with the sari (that he had lent her when she first found herself on his boat) to the tree trunk (378). In the light of the sense of separateness that is so significant an element for the novel's aesthetics and ethics, this position, where the two, man and woman, do not face each other, are not subject and object, but are actually positioned 'next to' or 'alongside' is crucial. The storm, natural to the tide country, creates the occasion for this final expression of equality between Piya and Fokir that has been implicit in their approach to each other throughout the novel. And the respect for the invisible line that keeps each living thing separate and whole is dramatically presented in the tiger, "several hundred metres away" standing and watching them before calmly swimming away (389). The end, where the storm "had fused them together and made them one," (390) on first reading appears slightly problematic in the light of this aesthetic of dividing lines. But appropriately perhaps, and in line with the fine restraint with which Ghosh has treated the Piya-Fokir intimacy, this is a moment when Fokir is already dead, since this is one relationship that needed the tide country and the mohonas to sustain its evenness and would not have survived in any other space or time. Earlier in the novel Piya reflects on

the unusually varied composition of the water itself. The waters of river and sea did not intermingle evenly in this part of the delta; rather, they interpenetrated each other, creating hundreds of different ecological niches with streams of fresh water running along the floors of some channels, creating variations of salinity and turbidity. (125) 
The waters do not blend and lose their character even if the tide erases divisions. Rather, complete little worlds are formed that exist alongside each other, each different and separate even as the waters flow together. This is not just a description of the tide country but reflects the way in which the individual and collective lives and the domains of human, animal, goddess and demon intersect and flow into each other and yet retain sanctity and separateness. And the narrative takes on this feature of easy flow and interpenetration as characters inhabit distinctive and separate worlds even as they meet and interact. Subaltern geoaesthetics is this quality of artistic work in the novel that takes off from subaltern practice but then moves beyond it.

Nandana DutTA

Gauhati University

\section{Works Cited}

Anand, Divya. "Words on Water: Nature and Agency in Amitav Ghosh's The Hungry Tide." Concentric: Literary and Cultural Studies 34.1 (March 2008): 21-44.

Ao, Temsula. These Hills Called Home: Stories from a War Zone. New Delhi: Penguin Zubaan, 2006.

Barras, Arnaud. "The Aesthetics of the Tide: The Ecosystem as Matrix for Transculturation in Amitav Ghosh's The Hungry Tide." Transculturation and Aesthetics: Ambivalence, Power, and Literature. Ed. Joel Kuortti. Amsterdam: Rodopi. 2015. 171-86.

Bнавна, Homi. The Location of Culture. London: Routledge, 1994.

BHADRA, Gautam. "The Mentality of Subalternity: Kantanama or Rajdharma." Subaltern Studies VI: Writings on South Asian History and Society. Ed. Ranajit Guha. Delhi: OUP, 1994. 54-91.

DAS, Veena. "Subaltern as Perspective." Subaltern Studies VI: Writings on South Asian History and Society. Ed. Ranajit Guha. Delhi: OUP, 1994. 310-24.

Garcia, Christina, ed. Bordering Fires: The Vintage Book of Contemporary Mexican and Chicano/ a Literature. New York: Vintage, 2006.

GHosh, Amitav. The Hungry Tide. New Delhi: Harper Collins, 2005.

—. "Postcolonial' Describes You as a Negative." Interview with T. Vijay Kumar. Interventions 9.1 (2007): 99-105.

GuHA, Ranajit. "Preface." Subaltern Studies 1: Writings on South Asian History and Society. Delhi: OUP, 1982. vii-viii.

—. "The Prose of Counter-Insurgency." Ranajit Guba, The Small Voice of History: Collected Essays. New Delhi: Permanent Black, 2010. 194-238.

Guignery, Vanessa. “'Step across this line': Edges and Borders in Contemporary Indian Literature." Études anglaises 62.3 (2009): 305-16.

Huggan, Graham and Helen Tiffin. Postcolonial Criticism: Literature, Animals, Environment. London and New York: Routledge, 2010.

IrIgaray, Luce. Between East and West: From Singularity to Community. Trans. Stephen Pluháček. New York: Columbia UP, 2002.

Latorre, Guisela. "Border Consciousness and Artivist Aesthetics: Richard Lou's Performance and Multimedia Artwork." American Studies Journal 57 (2012) np. 1 September $2015<\underline{\text { http://www. }}$ asjournal.org/57-2012/richard-lous-performance-and-multimedia-artwork/>.

Mondol, Anshuman. Amitav Ghosh. New Delhi: Viva Books, 2010.

Prakash, Gyan. "Postcolonial Criticism and Indian Historiography." Social Text 31-32, Third World and Post-Colonial Issues (1992): 8-19.

Roy, Anjali Gera. "Ordinary People on the Move: Subaltern Cosmopolitanisms in Amitav Ghosh's Writings." Asiatic 6.1 (June 2012): 32-46.

Schendel, Willem van. The Bengal Borderland: Beyond State and Nation in South Asia. London: Anthem, 2005.

Su, John J. "Amitav Ghosh and the Aesthetic Turn in Postcolonial Studies." Journal of Modern Literature 34. 3 (Spring 2011): 65-86. 